\title{
IDENTIFIKASI MASALAH MUSKULOSKELETAL PADA PENGENDARA TRANSPORTASI UMUM
}

\author{
Khalil Gibran, Wan Nishfa Dewi², Siti Rahmalia ${ }^{3}$ \\ ${ }^{1,2,3}$ Fakultas Keperawatan Universitas Riau \\ Fakultas Keperawatan Universitas Riau Jalan Pattimura No 9 \\ Gedung G Pekanbaru Riau Kode Pos 28131 Indonesia \\ Email: khalilgibran222@gmail.com
}

\begin{abstract}
Abstrak
Masalah muskuloskeletal merupakan yang timbul pada usia produktif seperti pada pekerja khususnya pengendara. Masalah muskuloskeletal yang umum diketahui terdapat pada pekerja yaitu carpal tunnel syndrome dan nyeri punggung bawah. Penelitian ini bertujuan untuk mengidentifikasi masalah muskuloskeletal pada pengendara trasnportasi umum. Desain penelitian ini menggunakan desain deskriptif sederhana dengan pendekatan cross sectional. Sampel penelitian ini berjumlah 100 pengendara atau pengemudi yang berkendara lebih dari 4,5 jam perhari yang menggunakan stratified random sampling. Alat ukur yang digunakan dalam penelitian ini yaitu kuesioner berdasarkan konsep dan teori. Hasil penelitian menunjukkan bahwa mayoritas responden berada pada rentang umur dewasa awal (22-40 tahun) (79,8\%), jenis kelamin laki-laki sebanyak (92,9\%), mayoritas indeks massa tubuh dengan kategori obese $(59,6 \%)$, dan dengan durasi bekerja lebih dari 8 jam $(81,8 \%)$, pada masalah muskuloskeletal carpal tunnel syndrome mayoritas tidak mengalami $(56,6 \%)$ dan nyeri punggung bawah mayoritas mengalami $(60,9 \%)$. Penelitian ini diharapkan dapat menjadi saran dan masukan bagi responden agar dapat meningkatkan derajat kesehatan dan mencegah potensi masalah yang berkaitan dengan gangguan muskuloskeletal.
\end{abstract}

Kata kunci: masalah muskuloskeletal, pengendara, transportasi umum

\begin{abstract}
Syndrome of muskuloskeletal disorders are occuring in productive ages such as to worker especially driver. The most common disordes that occur to driver are carpal tunnel syndrome and low back pain. The aim of this research is to identify syndrome of musculoskeletal disorders occur to public transportation driver. This research used quantitative descriptive research design using cross sectional method. The sample of this research was 100 drivers or riders who drive or ride above 4.5 hours a day with stratified random sampling technique. The instrument used in this research was a questionnaire based on theoretical evidence. The result showed the most of respondents are adulthood (22-40 years old) respondents (79.8\%), the most gender was males (92.9\%), majority of body mass index was in obese category (59.6\%), and the most work duration found was more than 8 hours a day (81.8\%). In carpal tunnel syndrome majority of respondents who did not
\end{abstract}


Khalil Gibran, Wan Nishfa Dewi, dan Siti Rahmalia, Identifikasi Masalah Muskuloskeletal pada Pengendara Transportasi Umum.

have any syndrome were bigger (56.6\%) and in low back pain majority of respondents had the syndromes were bigger (60.6\%). This research expected that respondents to being aware of increasing health status for all drivers to reduce potential problems related to muskuloskeletal.

Keywords: driver, musculoskeletal disorders, public transportation

\section{PENDAHULUAN}

Sarana transportasi umum sudah dikenal mulai tahun 1662 dimana transportasi umum ini berfungsi sebagai penyedia angkutan bagi masyarakat umum dengan dipugut bayaran mulai jarak dekat hingga jarak jauh (Permenhub 2017). Transportasi umum seperti bis, taksi, dan ojek, baik itu online maupun offline selalu digunakan, dikarenakan keberadaannya yang hampir selalu available 24 jam dalam sehari dan terjangkau untuk seluruh lapisan masyarakat.

Pengendara transportasi umum tidak sedikit yang menambah jam kerja 15 jam perhari untuk mendapatkan pendapatan ekstra (Permenhub, 2017). Pekerja transportasi umum yang sering bekerja mencapai 15 jam perhari akan menghabiskan waktu dengan duduk sepanjang hari terutama menghabiskan banyak waktu di mobil dan motor yang sangat rentan terjadi nyeri punggung (Davis \& Vini, 2009).
Ketahanan tubuh juga harus diperhatikan dalam kondisi berkendara. Keluhan nyeri punggung bawah cenderung dirasakan setelah 6 bulan, apabila pengendara sepeda motor berkendara secara rutin setiap hari minimal 2,5 jam, namun variabel waktu dapat berkurang bila pengendara tidak memiliki daya tahan tubuh yang baik terhadap posisi yang salah saat berkendara (Torik, 2016). Lamanya waktu aktivitas kerja mengharuskan seorang pengendara transportasi umum mempertahankan posisi berkendara yang statis yang dapat menimbulkan keluhan pada sistem muskuloskeletal (Fahmi, 2015).

Masalah muskuloskeletal merupakan masalah yang mempengaruhi fungsi normal sistem muskuloskeletal akibat paparan berulang berbagai faktor risiko di tempat bekerja yang dapat menyebabkan permasalahan kerja yang signifikan akibat peningkatan kompensasi biaya kesehatan, penurunan produktivitas, dan rendahnya 
kualitas hidup. Penduduk pada rentang usia 18-55 tahun di Amerika Serikat mengalami keluhan nyeri pada punggung (Saputra, Kandou \& Kawatu, 2017). Posisi duduk saat bekerja tidak hanya terdapat di perkantoran atau industri saja, namun berkendara dengan mobil khususnya pengemudi angkutan kota juga termasuk pekerjaan dengan posisi duduk (Enrico, 2016). Hasil studi yang pernah dilakukan terhadap lebih kurang 9000 pekerja di 12 kota, pada umumnya berupa penyakit muskuloskeletal (16\%), yang mana menjadi masalah tertinggi dibandingkan masalah kesehatan lainnya. Pekerjaan sebagai pengemudi angkutan kota rentan terhadap masalah kesehatan, misalnya nyeri punggung atau muskuloskeletal (Depkes, 2006).

Masalah kesehatan yang umum terjadi pada pengendara transportasi umum adalah nyeri punggung bawah dan carpal tunnel syndrome, nyeri punggung bawah sering dialami oleh pengendara transportasi umum. Hal ini didukung dengan penelitian Harnoto (2009) bahwa pekerja sebagai pengendara yang bekerja dengan durasi lama dan posisi yang statis dapat terkena masalah muskuloskeletal nyeri punggung bawah sedangkan carpal tunnel syndrome diakibatkan dari peregangan pergelangan tangan dan jari-jari secara berulang yang ditandai dengan rasa kesemutan pada ibu jari telunjuk dan jari tengah (CCOHS, 2014). Hal tersebut didukung oleh penelitian Sekaaram (2017) bahwa pengendara dengan jam kerja $\geq 4$ jam dapat menyebabkan tangan menjadi kram dan kesemutan.

Data untuk jumlah penderita NPB di Indonesia tidak diketahui secara pasti, namun diperkirakan penderita NPB di Indonesia berkisar $7,6 \%$ sampai $37 \%$. Data terkait jumlah penderita NPB di Kalimantan Barat khususnya di salah satu RSUD di Pontianak didapatkan bahwa pada tahun 2010 sebanyak 189 kasus, tahun 2011 sebanyak 63 kasus dan tahun 2012 sebanyak 959 kasus (Widianti, Basuki \& Jannis, 2009) dan prevalensi carpal tunnel syndrome pada pekerja orang dewasa adalah sebesar $6,7 \%$ dan prevalensi pada tahun 2012 adalah 3,1\%. Angka ini mewakili sekitar 4,8 juta pekerja yang didiagnosis dengan carpal tunnel syndrome. Tiga juta diantaranya merupakan work-related carpal tunnel 
Khalil Gibran, Wan Nishfa Dewi, dan Siti Rahmalia, Identifikasi Masalah Muskuloskeletal pada Pengendara Transportasi Umum.

syndrome (Luckhaupt et al, 2009).

Berdasarkan studi pendahuluan yang dilakukan di kota Pekanbaru khususnya di kelurahan Cinta Raja Kecamatan Sail Kota Pekanbaru, Riau didapatkan 15 pengendara transportasi umum diantaranya pengendara angkutan kota, dan pengendara bis dengan jumlah rata-rata jam bekerja 15 jam/hari mendapati nyeri di tangan, punggung, dan pinggang saat berkendara dan berdampak pada aktivitas keseharian seperti nyeri dan pegal pada tangan, kaki dan badan dimalam hari hingga pagi hari. Hal tersebut membuat peneliti tertarik untuk mengidentifikasi masalah muskuloskeletal pada pengendara transportasi umum.

Penelitian ini betujuan untuk mengidentifikasi masalah muskuloskeletal yang dapat terjadi pada pengendara transportasi umum.

\section{METODE PENELITIAN}

Desain penelitian ini adalah deskriptif sederhana dengan pendekatan cross sectional. Penelitian ini bertujuan untuk mengidentifikasi masalah muskuloskeletal pada pengendara transportasi umum.

Populasi dan sampel dalam penelitian ini sebanyak 100 responden yang diambil sesuai dengan kriteria inklusi yaitu responden yang berkendara lebih dari 4,5 jam dalam sehari. Teknik sampling yang digunakan dalam penelitian ini adalah stratified random sampling. Responden yang telah menandatangani informed consent akan mengisi dua kuesioner yaitu kuesioner masalah muskuloskeletal carpal tunnel syndrome (CTS) dan nyeri punggung bawah (NPB).

Analisis univariat dilakukan untuk melihat karakteristik responden meliputi usia, jenis kelamin, dan gambaran masalah CTS dan NPB berdasarkan setiap karakteristik responden.

\section{HASIL PENELITIAN}

\section{A. Analisa univariat}

\section{Karakteristik responden}

Tabel 1

Distribusi frekuensi karakteristik umur, jenis kelamin, indeks masa tubuh dan durasi Kerja 


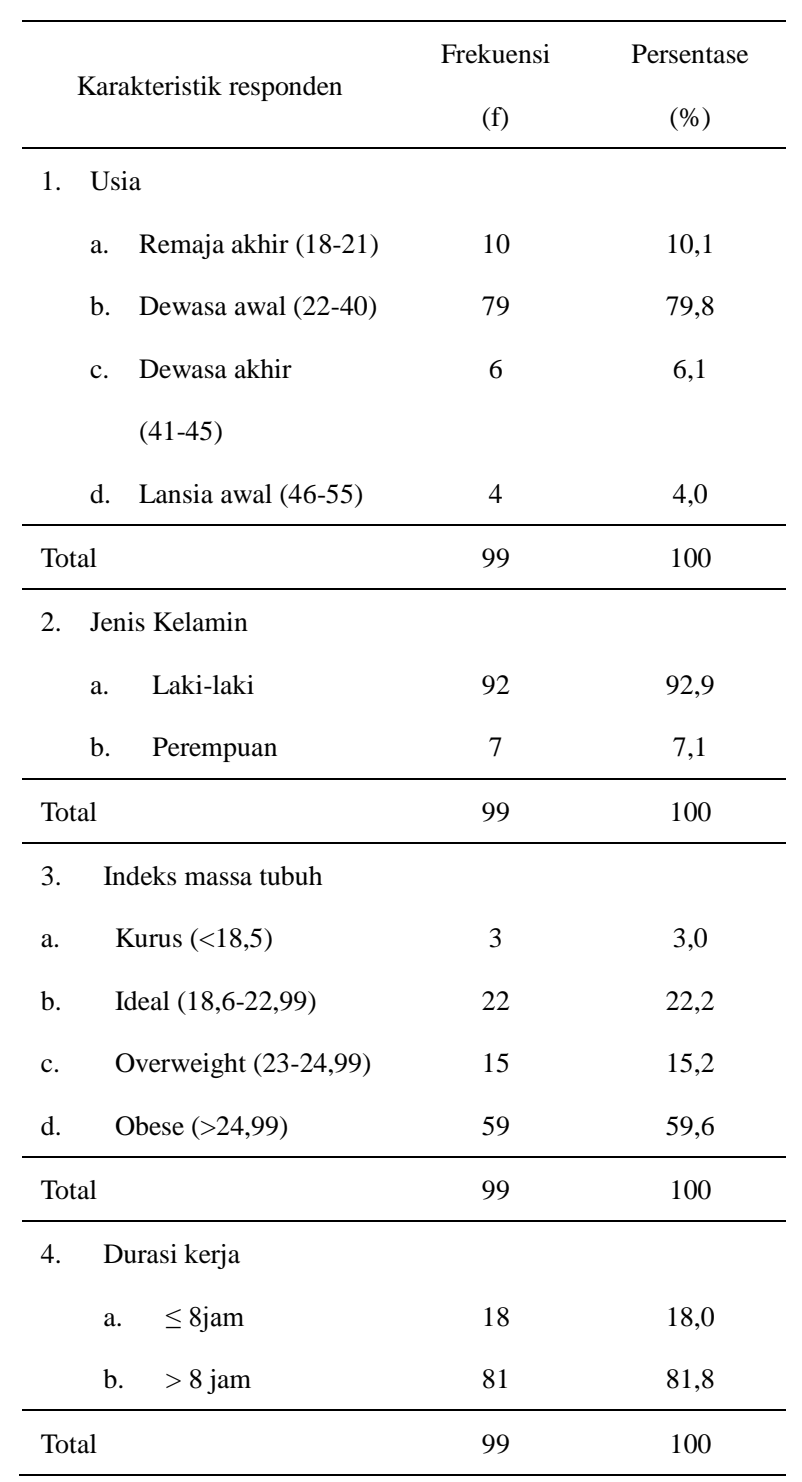

Tabel 1 menunjukkan bahwa dari 100 responden didapatkan sebagian besar responden yaitu dewasa awal (22- 40 tahun) $(79,8 \%)$. Mayoritas responden berjenis kelamin laki-laki (92,9\%). Mayoritas responden dengan IMT skala obese $(59,6 \%)$ dan mayoritas responden dengan jam kerja lebih dari 8 jam $(81,8 \%)$.

\section{Gambaran masalah muskuloskeletal}

Tabel 2

Distribusi frekuensi masalah CTS dan NPB

\begin{tabular}{lcc}
\hline Masalah Muskuloskeletal & Frekuensi (f) & Persentase (\%) \\
\hline $\begin{array}{l}\text { 1. CTS } \\
\text { • Tidak ada }\end{array}$ & 56 & 56,6 \\
• Ada & 43 & 43,4 \\
\hline Total & 99 & 100 \\
\hline 2. NPB & & \\
• Tidak ada & 39 & 39,4 \\
• Ada & 69 & 60,6 \\
\hline Total & 99 & 100 \\
\hline
\end{tabular}

Tabel 2 menujukkan bahwa dari 100 responden, sebagian besar mengalami masalah Carpal tunnel syndrome $(43,4 \%)$ dan mengalami masalah nyeri punggung bawah $(60,9 \%)$

\section{Gambaran masalah muskuloskeletal berdasarkan kelompok umur}

Tabel 3

Gambaran masalah muskuloskeletal berdasarkan kelompok umur

\begin{tabular}{ccccccc}
\hline & \multirow{2}{*}{ Usia } & \multicolumn{3}{c}{ Carpal tunnel syndrome } & \multicolumn{2}{l}{} \\
\cline { 2 - 5 } & \multicolumn{2}{c}{ Ada } & \multicolumn{2}{c}{ Tidak ada } & \multicolumn{2}{c}{ Total } \\
\cline { 2 - 6 } & $\mathrm{n}$ & $\%$ & $\mathrm{n}$ & $\%$ & $\mathrm{n}$ & $\%$ \\
\hline Remaja & 4 & 40 & 6 & 60 & 10 & 100 \\
akhir & & & & & & \\
\hline Dewasa & 35 & 44,3 & 44 & 55,7 & 79 & 100 \\
awal & & & & & & \\
\hline Dewasa & 3 & 50 & 3 & 50 & 6 & 100 \\
akhir & & & & & & \\
\hline Lansia & 1 & 25 & 3 & 75 & 4 & 100 \\
awal & & & & & & \\
\hline Total & 43 & & 56 & & 99 & 100 \\
\hline
\end{tabular}


Khalil Gibran, Wan Nishfa Dewi, dan Siti Rahmalia, Identifikasi Masalah Muskuloskeletal pada Pengendara Transportasi Umum.

\begin{tabular}{ccccccc}
\hline \multirow{2}{*}{ Usia } & \multicolumn{3}{c}{ Nyeri punggung bawah } & \multicolumn{2}{c}{ Total } \\
\cline { 2 - 5 } & \multicolumn{3}{c}{ Ada } & \multicolumn{2}{c}{ Tidak ada } & \\
\cline { 2 - 6 } & $\mathrm{n}$ & $\%$ & $\mathrm{n}$ & $\%$ & $\mathrm{n}$ & $\%$ \\
\hline Remaja & 3 & 30 & 7 & 70 & 10 & 100 \\
akhir & & & & & & \\
\hline Dewasa & 59 & 63,3 & 29 & 36,7 & 80 & 100 \\
awal & & & & & & \\
\hline Dewasa & 4 & 66,7 & 2 & 33,3 & 6 & 100 \\
akhir & & & & & & \\
\hline Lansia & 3 & 75 & 1 & 25 & 4 & 100 \\
awal & & & & & & \\
\hline Total & 60 & & 39 & & 99 & 100 \\
\hline
\end{tabular}

Tabel 3 didapatkan mayoritas responden dengan rentang usia dewasa akhir mengalami carpal tunnel syndrome (50\%) dan mengalami nyeri punggung bawah $(66,7 \%)$.

\section{Gambaran masalah muskuloskeletal berdasarkan jenis kelamin}

Tabel 4

Gambaran masalah muskuloskeletal berdasarkan jenis kelamin

\begin{tabular}{|c|c|c|c|c|c|c|}
\hline \multirow{3}{*}{$\begin{array}{c}\text { Jenis } \\
\text { kelamin }\end{array}$} & \multicolumn{4}{|c|}{ Carpal tunnel syndrome } & & \\
\hline & \multicolumn{2}{|c|}{ Ada } & \multicolumn{2}{|c|}{ Tidak ada } & \multicolumn{2}{|c|}{ Total } \\
\hline & $\mathrm{N}$ & $\%$ & $\mathrm{n}$ & $\%$ & $\mathrm{n}$ & $\%$ \\
\hline Laki-laki & 40 & 43,5 & 52 & 56,5 & 92 & 100 \\
\hline Perempuan & 3 & 42,9 & 4 & 57,1 & 7 & 100 \\
\hline Total & 43 & & 56 & & 99 & 100 \\
\hline Jenis & \multicolumn{4}{|c|}{ Nyeri punggung bawah } & & \\
\hline \multirow[t]{2}{*}{ kelamin } & \multicolumn{2}{|c|}{ Ada } & \multicolumn{2}{|c|}{ Tidak ada } & \multicolumn{2}{|c|}{ Total } \\
\hline & $\mathrm{N}$ & $\%$ & $\mathrm{n}$ & $\%$ & $\mathrm{n}$ & $\%$ \\
\hline Laki-laki & 56 & 60,9 & 37 & 39,1 & 92 & 100 \\
\hline Perempuan & 5 & 71,4 & 2 & 28,6 & 7 & 100 \\
\hline Total & 60 & & 39 & & 99 & 100 \\
\hline
\end{tabular}

Tabel 4 didapatkan bahwa responden berjenis kelamin Perempuan tidak mengalami carpal tunnel syndrome $(57,1 \%)$ dan responden dengan jenis kelamin Perempuan mengalami nyeri punggung bawah $(71,4 \%)$.

\section{Gambaran masalah muskuloskeletal}

\section{berdasarkan Indeks Massa Tubuh}

Tabel 5

Gambaran masalah muskuloskeletal berdasarkan Indeks Massa Tubuh

\begin{tabular}{|c|c|c|c|c|c|c|}
\hline \multirow[t]{3}{*}{ IMT } & \multicolumn{4}{|c|}{ Carpal tunnel syndrome } & & \\
\hline & \multicolumn{2}{|c|}{ Ada } & \multicolumn{2}{|c|}{ Tidak ada } & \multicolumn{2}{|c|}{ Total } \\
\hline & $\mathrm{n}$ & $\%$ & $\mathrm{n}$ & $\%$ & $\mathrm{n}$ & $\%$ \\
\hline Kurus & 1 & 33,3 & 2 & 66,7 & 3 & 100 \\
\hline Ideal & 9 & 40,9 & 13 & 59,1 & 22 & 100 \\
\hline Overweight & 6 & 40 & 9 & 60 & 15 & 100 \\
\hline Obese & 27 & 46,6 & 31 & 53,4 & 58 & 100 \\
\hline Total & 43 & & 56 & & 99 & 100 \\
\hline \multirow[t]{3}{*}{ IMT } & \multicolumn{4}{|c|}{ Nyeri Punggung Bawah } & & \\
\hline & \multicolumn{2}{|c|}{ Ada } & \multicolumn{2}{|c|}{ Tidak ada } & \multicolumn{2}{|c|}{ Total } \\
\hline & $\mathrm{n}$ & $\%$ & $\mathrm{n}$ & $\%$ & $\mathrm{n}$ & $\%$ \\
\hline Kurus & 1 & 33,3 & 2 & 66,7 & 3 & 100 \\
\hline Ideal & 14 & 63,6 & 8 & 36,4 & 22 & 100 \\
\hline Overweight & 9 & 60 & 6 & 40 & 15 & 100 \\
\hline Obese & 35 & 60,3 & 24 & 39,7 & 59 & 100 \\
\hline Total & 60 & & 39 & & 99 & 100 \\
\hline
\end{tabular}

Tabel 5 menunjukkan bahwa mayoritas responden didapatkan dengan IMT obese mengalami Carpal Tunnel Syndrome (46,6\%) dan mayoritas responden dengan obese tertinggi mengalami nyeri punggung bawah $(60,3 \%)$ 
6. Gambaran masalah muskuloskeletal berdasarkan durasi kerja dalam sehari

Tabel 6

Gambaran masalah muskuloskeletal berdasarkan durasi kerja dalam sehari

\begin{tabular}{|c|c|c|c|c|c|c|}
\hline \multirow[t]{3}{*}{ Durasi Kerja } & \multicolumn{4}{|c|}{ Carpal tunnel syndrome } & & \\
\hline & \multicolumn{2}{|c|}{ Ada } & \multicolumn{2}{|c|}{ Tidak ada } & \multicolumn{2}{|c|}{ Total } \\
\hline & $\mathrm{N}$ & $\%$ & $\mathrm{n}$ & $\%$ & $\mathrm{n}$ & $\%$ \\
\hline$\leq 8$ jam & 8 & 47,1 & 9 & 52,9 & 17 & 100 \\
\hline$>8$ jam & 35 & 43,2 & 46 & 56,8 & 81 & 100 \\
\hline Total & 43 & & 56 & & 99 & 100 \\
\hline \multirow[t]{3}{*}{ Durasi Kerja } & \multicolumn{4}{|c|}{ Nyeri punggung bawah } & & \\
\hline & \multicolumn{2}{|c|}{ Ada } & \multicolumn{2}{|c|}{ Tidak ada } & \multicolumn{2}{|c|}{ Total } \\
\hline & $\mathrm{N}$ & $\%$ & $\mathrm{n}$ & $\%$ & $\mathrm{n}$ & $\%$ \\
\hline$\leq 8$ jam & 11 & 64,7 & 7 & 35,3 & 18 & 100 \\
\hline$>8$ jam & 49 & 61,1 & 32 & 38,9 & 81 & 100 \\
\hline Total & 60 & & 39 & & 99 & 100 \\
\hline
\end{tabular}

Tabel 6 menunjukkan bahwa mayoritas responden dengan durasi kerja $>8$ jam tidak mengalami carpal tunnel syndrome $(56,8 \%)$ dan mengalami nyeri punggung bawah $(61,1 \%)$.

\section{PEMBAHASAN}

A. Pembahasan hasil penelitian

\section{Karakteristik responden}

a. Umur

Berdasarkan hasil penelitian yang telah dilakukan didapatkan bahwa mayoritas umur responden ialah 22-40 tahun (dewasa awal) $(79,8 \%)$. Usia dewasa awal adalah usia produktif bagi seseorang dalam bekerja untuk memenuhi kebutuhan hidup terutama bagi pengendara trasnportasi umum dan apabila tidak mampu menjaga kesehatan dengan baik akan berdampak munculnya keluhan pada kesehatannya seperti pada sistem muskuloskeletal. Hal ini sejalan dengan penelitian yang dilakukan oleh Enrico (2016) bahwa karateristik responden dalam rentang umur dewasa awal paling banyak mengalami keluhan muskuloskeletal (50,7\%).

b. Jenis kelamin

Berdasarkan hasil penelitian didapatkan mayoritas jenis kelamin para pengendara ialah laki-laki sebanyak 93 orang $(92,9 \%)$. Peneliti berasumsi dalam penelitian ini lebih banyak masalah muskuloskeletal pada laki-laki dikarenakan jumlah responden laki-laki jauh lebih besar dari pada perempuan. Hal ini sejalan dengan penelitian Wijayanti (2019) di dalam penelitianya ditemukan lebih banyak responden laki-laki dibandingkan perempuan $(86 \%)$. Wanita lebih cenderung mengalami masalah muskuloskeletal dikarenakan kekuatan dan kemampuan otot wanita lebih kecil. Hal ini dikuatkan dengan penelitian 
Khalil Gibran, Wan Nishfa Dewi, dan Siti Rahmalia, Identifikasi Masalah Muskuloskeletal pada Pengendara Transportasi Umum.

Silviyani (2013) yang menyatakan bahwa wanita lebih berpotensi mengalami masalah muskuloskeletal dikarenakan rata-rata kekuatan otot wanita hanya sebesar $60 \%$ dibanding pria dan hormon pada wanita cenderung mengikat lemak dari pada membangun massa otot.

c. IMT

Hasil penelitian yang telah dilakukan didapatkan pengendara memiliki IMT dalam kategori obesitas $(59,6 \%)$. Obesitas yang memicu penyakit metabolis juga dapat meningkatkan risiko mengalami kelainan muskuloskeletal. Hal ini sejalan dengan penelitian yang dilakukan oleh Gunawan (2015) yang menyatakan bahwa responden dengan obesitas lebih mudah mengalami masalah muskuloskeletal (30\%) dikarenakan berat badan yang meningkat menyebabkan otot harus bekerja lebih keras menopang tubuh.

\section{d. Durasi kerja}

Hasil penelitian yang telah dilakukan didapatkan mayoritas pengendara bekerja lebih dari 8 jam (81,8\%). Memperpanjang waktu bekerja lebih dari kemampuan kerja biasanya tidak efektif dan efisien karena akan membuat tubuh kelelahan dan tidak fokus dalam bekerja. Hal ini sejalan dengan penelitian yang dilakukan oleh Anjanny (2019) yang menyatakan bahwa responden bekerja lebih dari 8 jam dalam sehari $(86,5 \%)$.

\section{Gambaran masalah musculoskeletal}

\section{berdasarkan karakteristik responden}

1. Gambaran masalah carpal tunnel syndrome berdasarkan kelompok umur.

Berdasarkan penelitian yang dilakukan didapatkan bahwa responden dengan rentang usia dewasa akhir mengalami carpal tunnel syndrome (CTS) (50\%). Peneliti berasumsi bahwa responden dengan usia dewasa akhir banyak mengalami CTS dikarenakan usia dewasa akhir adalah usia dimana organ muskuloskeletal mengalami penurunan fungsi. Hal ini sejalan dengan penelitian Farhan dan Kamrasyid (2018) yang menyatakan bahwa carpal tunnel syndrome cenderung terdapat pada usia 40-60 tahun $(81,2 \%)$.

2. Gambaran masalah carpal tunnel syndrome berdasarkan jenis kelamin Berdasarkan penelitian yang dilakukan didapatkan bahwa mayoritas responden 
dengan jenis kelamin laki-laki mengalami masalah CTS $(43,5 \%)$ dan perempuan tidak mengalami CTS (56,5\%) dimana sudah mencapai angka yang cukup tinggi. Hal ini sejalan dengan penelitian Fitriani (2012) bahwa lebih banyak responden yang mengalami CTS berjenis kelamin laki-laki sebanyak 38 orang $(66,7 \%)$. Hal ini juga dapat disebabkan oleh kemampuan laki-laki yang lebih banyak mengeluarkan tenaga dalam bekerja khususnya bagian otot dan tulang.

3. Gambaran masalah carpal tunnel syndrome berdasarkan Indeks Massa Tubuh

Peneliti berasumsi orang dengan IMT tinggi beresiko mengalami masalah muskuloskeletal akibat masa tubuh yang besar dapat mempengaruhi kinerja dan beban anggota tubuh. Berdasarkan penelitian yang dilakukan didapatkan bahwa responden dengan IMT rentang obese mengalami CTS (46,6\%). Sejalan dengan penelitian oleh Wulandari (2016) ditemukan bahwa responden dengan IMT >25 paling banyak mengalami CTS (52,6\%). Seseorang dengan status gizi yang berlebih dapat mengisi carpal tunnel dan meningkatkan kemungkinan terjadinya CTS pada orang tersebut.

4. Gambaran masalah carpal tunnel syndrome berdasarkandurasi kerja

Berdasarkan penelitian yang dilakukan terhadap 99 responden di dapatkan bahwa mayoritas responden dengan durasi kerja lebih dari 8 jam tidak mengalami CTS (56,8\%). Hal ini tidak sejalan dengan penelitian Basuki (2019) bahwa ada hubungan antara durasi kerja dengan CTS dibuktikan dengan banyaknya responden yang postitif mengalami CTS dengan durasi kerja lebih dari 8 jam sebanyak 30 orang $(89 \%)$. Peneliti berasumsi bahwa semakin lama durasi bekerja dalam sehari maka semakin banyak tenaga yang digunakan juga semakin sering otot dan tulang bekerja dan dan diberi beban yang mana itu dapat mempengaruhi fungsi dan kekuatan organ itu sendiri seperti timbulnya keluhan dan masalah muskuloskeletal bahkan hingga penyakit muskuloskeletal.

5. Gambaran masalah nyeri punggung bawah berdasarkan kelompok umur. 
Khalil Gibran, Wan Nishfa Dewi, dan Siti Rahmalia, Identifikasi Masalah Muskuloskeletal pada Pengendara Transportasi Umum.

Dari hasil penelitian yang telah dilakukan didapatkan bahwa responden dengan kategori usia dewasa akhir (22-40) tahun mengalami masalah nyeri punggung $(66,7 \%)$. Peneliti berasumsi bahwa usia dewasa akhir adalah usia dimana seseorang akan mengalami penurunan fungsi tubuh. Tarwaka (2010) mengatakan, masalah muskuloseletal dirasakan pada usia 25-65 tahun dan keluhan bisa meningkat seiring bertambahnya umur.

6. Gambaran masalah nyeri punggung bawah berdasarkan jenis kelamin.

Terkait dengan hasil penelitian yang telah dilakukan jenis kelamin yang memiliki masalah nyeri punggung ialah perempuan (71,4\%). Hal ini sejalan dengan penelitian Silviyani (2013) yang menyatakan bahwa wanita lebih berpotensi mengalami masalah muskuloskeletal dikarenakan rata-rata kekuatan otot wanita hanya sebesar $60 \%$ dibanding pria dan hormon pada wanita cenderung mengikat lemak daripada membangun massa otot.

7. Gambaran masalah nyeri punggung bawah berdasarkan indeks massa tubuh.
Responden dengan IMT obese (60,3\%). Peningkatan berat badan hingga obesitas dapat meningkatkan tekanan pada tulang punggung dan pinggang khususnya lumbal dan lumbosakral yang mana menopang tubuh secara besar beresiko menyebabkan meyebabkan timbulnya gangguan kesehatan baik secara fisik maupun secara fungsi seperti bengkaknya diskus antar tulang atau nyeri. Hal ini sejalan dengan penelitian yang dilakukan Purnamasari (2010) bahwa responden dengan IMT diatas normal terbanyak mengalami nyeri punggung $(65,6 \%)$.

8. Gambaran masalah nyeri punggung bawah berdasarkan durasi kerja.

Berdasarkan hasil penelitian yang telah dilakukan dapat dilihat bahwa responden yang paling banyak terkena nyeri punggung bawah ialah responden dengan durasi kerja lebih dari 8 jam $(61,7 \%)$. Semakin lama durasi kerja maka semakin meningkat pula kerja anggota tubuh terutama bagian tulang punngung yang menopang berat badan. Pada penelitian yang dilakukan oleh Sasamu (2019) di dapatkan bahwa responden dengan durasi jam kerja lebih dari 8 jam paling banyak mengalami 
nyeri punggung bawah $(83,9 \%)$.

\section{SIMPULAN}

Berdasarkan hasil penelitian yang dilakukan di Kota Pekanbaru dapat disimpulkan bahwa mayoritas umur responden yang melakukan pengisian kuesioner berada dalam rentang umur dewasa awal (22-40 tahun $(79,8 \%)$ dengan mayoritas jenis kelamin yang ditemukan ialah laki-laki $(92,9 \%)$, responden memiliki Indeks Massa Tubuh (IMT) obese atau obesitas $(59,6 \%)$ dan dengan mayoritas durasi kerja lebih dari 8 jam $(81,8 \%)$. Hasil penelitian ini menunjukkan bahwa gambaran masalah muskuloskeletal pada pengendara khususnya Carpal tunnel syndrome mengalami sebesar $43,4 \%$ dan nyeri punggung bawah sebesar $60,6 \%$

\section{SARAN}

Bagi perkembangan Ilmu Keperawatan, hasil penelitian ini dapat dijadikan sebagai pengembangan ilmu keperawatan khususnya mahasiswa keperawatan agar dapaat mengembangkan variabel tentang masalah muskuloskeletal lain yang umumnya terjadi di dunia kerja.

Bagi Institusi tempat penelitian, hasil penelitian ini diharapkan dapat menjadi tolak ukur bagi institusi untuk memperhatikan dan meningkatkan derajat kesehatan dan keselamatan kerja para pekerja yang bekerja di bawah manajemen institusi terkait masalah muskuloskeletal yang umum terjadi pada pengendara transportasi umum.

Bagi responden, hasil penelitian ini diharapkan dapat menjadi pengetahuan bagi para pengendara transportasi umum dalam menjaga dan meningkatkan kesehatan terkait masalah muskuloskeletal.

Bagi peneliti selanjutnya, hasil penelitian ini dapat dijadikan sebagai evidence based untuk mengembangkan penelitian yang lebih spesifik dengan mengembangkan variabel-variabel yang berhubungan dengan masalah muskuloskeletal. Peneliti selanjutnya disarankan untuk menggali lebih spesifik tentang hubungan masalah muskuloskeletal Low back pain terhadap activity daily life pada ranah pekerjaan yang lain. 
Khalil Gibran, Wan Nishfa Dewi, dan Siti Rahmalia, Identifikasi Masalah Muskuloskeletal pada Pengendara Transportasi Umum.

\section{DAFTAR PUSTAKA}

Anjanny, A. (2019). Keluhan muskuloskeletal disorder (MSDs) pada pekerja pengguna computer di Badan Pusat Statistik Provinsi Sumatera utara. Jurnal kesehatan global: Institut Kesehatan Helvetia Medan. Diperoleh tanggal 17 Juni 2019 dari http://ejournal.helvetia.ac.id/index.php/j $\mathrm{kg} /$ article/view/4068/146

Basuki, R. (2015). Faktor prediktor carpal tunnel syndrome (CTS) pada pengrajin alat tenun bukan mesin (ATBM). Jurnal

Fakultas Kedokteran: Universitas

Muhammadiyah Semarang. Diperoleh tanggal 20 Juni 2019 dari https://jurnal.unimus.ac.id/index.php/ked okteran/article/view/2580

Canadian Centre for Occupational Health and Safety (2014). Work related muskuloskeletal disorders. Diperoleh tanggal 03 April 2013.

Davis, K \& Vini, T. (Ed.). 2009. Buku pintar nyeri tulang dan otot. Jakarta, Indonesia: Erlangga.

Enrico, J. M. (2016). Hubungan antara umur, lama kerja dan getatran dengan keluhan muskuloskeletal pada supir bus trayek bitung-manado di terminal tangkoko bitung tahun 2016. Jurnal Ilmiah Fakultas Kesehatan Masyarakat: Universitas Samratulangi diperoleh tanggal 08 April 2019 dari ejournal.unsrat.ac.id/index.php/ pharmacon/article/viewFile

Farhan, F. S., Kamrasyid, A. A. (2018). Faktor-faktor yang mempengaruhi timbulnya carpal tunnel syndrome pada pengendara ojek. Jurnal Fakultas Kedokteran dan Kesehatan: Universitas Muhammadiyah Jakarta. Diperoleh tanggal 20 Juni 2019 dari https://journal.umj.ac.id/index.php/tmj/ar ticle/view/2543/1491

Fitriani, R. N. (2012). Faktor-faktor yang berhubungan dengan dugaan carpal tunnel syndrome pada operator computer bagian sekretariat di Inspektorat Jenderal Dinas Pekerjaan Umum tahun 2012. Jurnal Fakultas kedokteran: Universitas Islam Negeri Syarif Hidayatullah Jakarta. Diperoleh tanggal 20 Juni 2019 dari http://repository.uinjkt.ac.id/dspace/bitstr eam/123456789/26000/1/ -fkik.pdf

Gunawan, I. M. K. (2015). Hubungan antara tipe kendaraan dan obesitas dengan risiko muskuloskeletal disorder (MSDs) pada mahasiswa pengendara sepeda motor di Universitas Udayana. Jurnal Ilmiah Faklutas Kedokteran: Univeritas Udayana Bali. Diperoleh tanggal 17 Juni 2019 dari

https://simdos.unud.ac.id/uploads/file Harnoto, H. (2009). Hubungan posisi duduk dengan timbulnya nyeri punggung Bawah pada pengemudi mobil. Jurnal Ilmiah Fakultas Ilmu Kesehatan: Universitas Muhammadiyah Surakarta. Diperoleh tanggal 24 Februari 2019 dari http://eprints.ums.ac.id/3940/1/J159.pdf

Luckhaupt et al. (2009). Prevalence and work relatedness of carpal tunnel syndrome in the working population, United States, 2010 national health interview survey. American Journal of Medicine. Diperoleh tanggal 15 Mei 2019 dari https://onlinelibrary.wiley.com/doi/abs/1 


\subsection{2/ajim.22048}

Peraturan Menteri Perhubungan Republik Indonesia. (2017). Penyelenggaraan angkutan orang dengan kendaraan bermotor umum tidak dalam trayek. Menhub.

Purnamasari, H., Gunarso, U., Rujito, L. (2010). Overweight sebagai faktor resiko low back pain pada pasien Poli Saraf RSUD Prof. Dr. Margono Soekarjo Purwokerto. Jurnal Fakultas Kedokteran dan Ilmu Kesehatan: Universitas Jenderal Soedirman Purwokerto. Diperoleh tanggal 20 Juni 2019 dari https://www.researchgate.net/profile/La ntip_Rujito/publication/pdf

Sasamu, V., Joseph, W. B. S \& Sondakh, R. C. (2019). Hubungan durasi mengemudi dan umur dengan kelihan nyeri punggung bawah pada pengemudi mikrolet jurusan karombasan - pusat kota Manado. Jurnal Fakultas

Kesehatan Masyarakat Universitas Sam Ratulangi. Diperoleh tanggal 20 Juni 2019 dari http://ejournalhealth.com/index.php/kes mas/article/view/489

Sekaaram, V. \& Ani, L.S. (2017). Prevalensi muskulosceletal disorders (MSDs) pada pengemudi angkutan umum di terminal Mengwi, kabupaten Bandung-Bali. Jurnal Ilmiah Fakultas Kedokteran. Universitas Udayana. Diperoleh tanggal 29 Desember 2018 dari https://docs.google.com/viewer?url=http s://www.isainsmedis.id/index.php /article/viewFile/125/140

Silviyani, V. (2013). Hubungan posisi bekerja petani lansia dengan resiko terjadinya nyeri punggung bawah di wilayah kerja puskesmas Sumberjambe Kabupaten Jember. Jurnal Ilmiah Fakultas Keperawatan: Universitas Jember. Diperoleh tanggal 17 Juni 2019 dari http://repository.unej.ac.id/handle/123456789/ 60740

Tarwaka. (2014). Ergonomi industri: Dasar-dasar pengetahuan ergonomi dan pengaplikasiannya di tempat kerja. Surakarta: Harapan Press

Torik. (2016). Analisa postur pengendara motor untuk mengevaluasi bagian tempat dudukan. Jurnal Ilmiah Fakultas Teknik: Universitas Mercu Buana Jakarta. Diperoleh tangga 24 Maret 2019 dari https://media.neliti.com/media/publicatio ns/165563-ID-analisa-postur-pengendara -motor-untuk-ev.pdf

Widiyanti E.C.L, Basuki E, Jannis J. (2009). Hubungan sikap tubuh saat mengangkat dan memindahkan pasien pada perawat perempuan dengan nyeri punggung bawah: Majalah Kedokteran Indonesia. Diperoleh tanggal 17 Mei 2019 dari http://jurnal.untan.ac.id/index.php/jfk/art icle/view/3855/3862

Wulandari, N. N. (2016). Hubungan umur, masa kerja, IMT dan frekuensi gerakan repetitif dengan kejadian carpal tunnel syndrome (Studi pada pekerja pemetik tangkai cabai). Jurnal Fakultas Kesehatan Masyarakat: Universitas Muhammadiyah Semarang. Diperoleh tanggal 20 Juni 2019 dari http://repository.unimus.ac.id/46/1/Manus cript\%201.pdf 